Editorial

\title{
Sustainable Fruit Growing: From Orchard to Table-Editorial Commentary
}

\author{
Boris Duralija
}

check for

Citation: Duralija, B. Sustainable Fruit Growing: From Orchard to Table-Editorial Commentary. Sustainability 2022, 14, 1053. https:// doi.org/10.3390/su14031053

Received: 12 January 2022

Accepted: 13 January 2022

Published: 18 January 2022

Publisher's Note: MDPI stays neutral with regard to jurisdictional claims in published maps and institutional affiliations.

Copyright: (C) 2022 by the author. Licensee MDPI, Basel, Switzerland. This article is an open access article distributed under the terms and conditions of the Creative Commons Attribution (CC BY) license (https:// creativecommons.org/licenses/by/ $4.0 /)$.
Department of Pomology, Division of Horticulture and Landscape Architecture, University of Zagreb Faculty of Agriculture, Svetošimunska cesta 25, 10000 Zagreb, Croatia; bduralija@agr.hr; Tel.: +385-1-2393726

Fruit production has faced many challenges in recent years as society seeks to increase fruit consumption while increasing safety and reducing the harmful effects of intensive farming practices (e.g., pesticides and fertilizers) [1]. In the last 50 years, the population has more than doubled and is expected to grow to 9 billion people by 2050 [2]. Per capita consumption of fruit is also increasing during this time and the global fruit industry is facing a major challenge to produce enough fruit in quantity and quality. The need for sustainable production of nutritious food is critical for human and environmental health.

Apple trees are grown on an area of about 4.6 million hectares and are the leading temperate fruits, producing more than 85 million tonnes in 2020, which is more than $10 \mathrm{~kg}$ for every single person in the world [3]. In the last 50 years (from 1970 to 2020), apple fruit production has increased threefold (220\%) compared to the area under cultivation (66\%) [3]. This is mainly due to intensification through the use of high-yielding varieties on suitable rootstocks, modern mechanization, synthetic fertilizers and pesticides. To be sustainable, an apple farm must produce adequate yields of high quality, be profitable, protect the environment, conserve resources, and be socially responsible in the long term [4,5]. For example, the use of plastic in apple orchards can be reduced by using the material several times in the same year or years, by using it in every other row, or by replacing it with another reflective material-an important step toward environmentally friendly, sustainable horticulture [6]. Thanks to the changes that have taken place in recent years in the field of image analysis methods and computational performance, it is possible to develop solutions for automatic fruit counting based on registered digital images and predict yield, which contributes to better planning of harvest [7].

The results of the life cycle assessment (LCA) of three farms growing six types of fruit showed that several production activities have a high impact on the environment: In descending order of absolute value, fruit refrigeration, agronomic operations, irrigation, and fertilizer use were found to have the greatest impact [8]. Other activities, such as the use of agrochemicals, planting and the use of plastic in harvesting and packaging, had lower overall impacts. The high environmental impacts associated with most production activities underscore the need to make primary food production cleaner, more resource-efficient, and less energy-intensive [8].

Climate change is more than ever an important issue for agriculture and fruit growers. Many new threats arising from it are present in the area of existing orchards, such as the accumulation of enough chill units, extreme low and high temperatures, droughts, storms, floods, stronger winds, frost damage, hail, the appearance of new pests, etc. Temperature is the most important environmental factor affecting fruit and nut trees and productivity because it affects tree physiology and the susceptibility of flower buds, flowers, and young fruits and nuts to low temperatures or spring frosts. Fruit and nut trees are at high risk of having buds, flowers and young fruits and nuts vulnerable to low temperatures in early spring because temperatures can still drop below $0{ }^{\circ} \mathrm{C}$ when ecodormancy ends and flowering and young fruit formation begin. Severe weather conditions, especially frost in winter and early spring, may pose a significant threat to sustainable nut and fruit 
production in some regions, while fruit and nut trees with high chilling requirements may not be able to meet chilling requirements in some areas [9].

Some new pests, such as the brown marmorated stink bug (Halyomorpha halys Stål, 1855), an invasive polyphagous species, are emerging in traditional fruit growing areas in the United States and Europe and threatening production. New safe insecticides should be introduced into practice for sustainable fruit growing, which includes reducing chemical pollution of the environment. Some new green insecticides whose use could increase safety in fruit production need to be explored. Potential candidates with insecticidal activity against the marmorated stink bug are microparticles loaded with leaves of Stevia rebaudiana (Bertoni) [10].

Wild edible fruits have a much greater diversity of species and are sometimes extremely resistant to adverse environmental conditions [11]. If we look at wild fruit plants that have grown without the help of humans, they can sustain themselves for centuries in the same area. For example, wild Himalayan figs (Ficus palmata Forssk.) are well adapted to local pedoclimatic conditions and, combined with easy propagation and production, can contribute to the local economy and have a significant impact on the socioeconomic and ecological balance. The results showed high variability in some of the studied traits of 35 accessions from different parts of northeast Pakistan, indicating their good potential for further improvement and use in sustainable agricultural production [12]. Results from the relatively limited number of sea buckthorn (Hippophae rhamnoides L. ssp. Caucasica Rousi) genotypes from Turkey show promise traits for further improvement in both horticultural and nutritional traits, indicating potentially even greater variability if more genotypes are to be considered in the future [13].

Based on the research mentioned in this Special Issue, it can be concluded that edible wild fruits may be an ideal model for how to approach modern intensive production and the principle of sustainability.

Some fruit species are still in the early stages of domestication, such as Cornelian cherry (Cornus mas L.), which has been grown wild in the Balkan Peninsula for centuries with no apparent problems with disease or pests. For these reasons, it is necessary to highlight the importance of local selection of cornelian cherries for sustainable cornelian cherry production in areas where new orchards are planned [14].

For reasons of mixing genes in sexual propagation in breeding programmes or in the wild, fruit plants are mainly propagated asexually in modern industrial production. When apricot cultivars are propagated asexually over a long period of time, they can produce interclonal variations that sometimes have better fruit characteristics than the original plant. The results of the study in this Special Issue have shown that clones of the apricot cultivar Sekerpare have a wide diversity of morphological characteristics and nutritional and nutraceutical compositions even at a small single site [15]. The concept of sustainable apricot production can be described as a "three-legged stool" whose legs are economic viability, environmental sustainability and social acceptability. Communicating the health benefits of apricots to consumers is essential for sustained demand for apricot products, which is a prerequisite for sustainable apricot production [15].

The quality of fruits for fresh consumption is mainly determined by their flavour, aroma, attractive appearance, and high content of bioactive compounds that play an important role in human nutrition. Peaches can serve as a source of sugars, mainly sucrose, as well as phenols, carotenoids and anthocyanins, and also provide valuable antioxidants. In the study from the Czech Republic, the Czech cultivar 'Krasava' was found to have a very high content of titratable acids, phenols, flavonoids and antioxidant capacity [16]. Pomological studies of fruit quality and consumer acceptance can give farmers clues as to which species and cultivars they can grow to be more successful in the market.

People are now increasingly concerned about the sustainability of fruit production and the fruit industry as a whole. Therefore, new studies that can take this into account will be needed in the future. 
More than 15 years ago, I convened the meeting "Berry Plant Quality and Sustainable Production" and was the guest editor of the Special Issue of the journal Agriculturae Conspectus Scientificus (ACS, Vol. 71, No. 4, 2006), in which 14 articles were published. Berries, as one of the most intensively produced fruits in Europe, were discussed from different aspects, from the quality of the starting material to alternative production strategies towards sustainability [17-19].

This time the Special Issue (SI) focused on different fruit species and aspects that can promote more sustainable fruit growing in the future. The SI "Sustainable Fruit Growing: From Orchard to Table" contains the following 11 commentary and research papers by 45 scientists from Australia, Bosnia and Herzegovina, Croatia, Czech Republic, Germany, Italy, Montenegro, Pakistan, Poland, Turkey and the United States:

1. Sustainable Fruit Growing: From Orchard to Table-Editorial Comentary

2. Innovative Strategies for the Use of Reflective Foils for Fruit Colouration to Reduce Plastic Use in Orchards [6]

3. Detecting Apples in the Wild: Potential for Harvest Quantity Estimation [7]

4. Interpreting Environmental Impacts Resulting from Fruit Cultivation in a Business Innovation Perspective [8]

5. Chilling and Heat Accumulation of Fruit and Nut Trees and Flower Bud Vulnerability to Early Spring Low Temperatures in New Mexico: Meteorological Approach [9]

6. Polyphenol-Based Microencapsulated Extracts as Novel Green Insecticides for Sustainable Management of Polyphagous Brown Marmorated Stink Bug (Halyomorpha halys Stål, 1855) [10]

7. Evaluation of the Characteristics of the Native Wild Himalayan Fig (Ficus palmata Forsk.) from Pakistan as a Potential Species for Sustainable Fruit Production [12]

8. Main Agro-Morphological and Biochemical Berry Characteristics of Wild-Grown Sea Buckthorn (Hippophae rhamnoides L. ssp. caucasica Rousi) Genotypes in Turkey [13]

9. Sustainable Cornelian Cherry Production in Montenegro: Importance of Local Genetic Resources [14]

10. Assessment of Morphological Traits, Nutritional and Nutraceutical Composition in Fruits of 18 Apricot cv. Sekerpare Clones [15]

11. Determination of Selected Beneficial Substances in Peach Fruits [16]

For this valuable collection of data, the editor would like to thank all the authors who submitted their articles for this Special Issue and congratulate them on the publication of their articles with Sustainability. This would not have been possible without the active support of all the Academic Editors and the dedicated reviewers with their constructive comments, for which I am very grateful. Last but not least, I would like to thank Prof. Dr. Marc A. Rosen, the Editor-in-Chief of Sustainability, Ms. Zero Xing, the Managing Editor, and the entire MDPI team for their support of this Special Issue.

Funding: This research received no external funding.

Institutional Review Board Statement: Not applicable.

Informed Consent Statement: Not applicable.

Data Availability Statement: Not applicable.

Conflicts of Interest: The author declares no conflict of interest.

\section{References}

1. Bursać Kovačević, D.; Brdar, D.; Fabečić, P.; Barba, F.J.; Lorenzo, J.M.; Putnik, P. Strategies to achieve a healthy and balanced diet: Fruits and vegetables as a natural source of bioactive compounds. In Agri-Food Industry Strategies for Healthy Diets and Sustainability; Academic Press: Cambridge, MA, USA, 2020; pp. 51-88.

2. Lam, D. How the World Survived the Population Bomb: Lessons From 50 Years of Extraordinary Demographic History. Demography 2011, 48, 1231-1262. [CrossRef]

3. Food and Agriculture Organization of the United Nations (FAO). Available online: http://www.fao.org/faostat/en/ (accessed on 11 January 2022). 
4. Reganold, J.P.; Glover, J.D.; Andrews, P.K.; Hinman, H.R. Sustainability of three apple production systems. Nature 2001, 410, 926-930. [CrossRef]

5. Duralija, B.; Putnik, P.; Brdar, D.; Bebek Markovinović, A.; Zavadlav, S.; Pateiro, M.; Domínguez, R.; Lorenzo, J.M.; Bursać Kovačević, D. The Perspective of Croatian Old Apple Cultivars in Extensive Farming for the Production of Functional Foods. Foods 2021, 10, 708. [CrossRef] [PubMed]

6. Hess, P.; Kunz, A.; Blanke, M.M. Innovative Strategies for the Use of Reflective Foils for Fruit Colouration to Reduce Plastic Use in Orchards. Sustainability 2020, 13, 73. [CrossRef]

7. Janowski, A.; Kaźmierczak, R.; Kowalczyk, C.; Szulwic, J. Detecting Apples in the Wild: Potential for Harvest Quantity Estimation. Sustainability 2021, 13, 8054. [CrossRef]

8. Medici, M.; Canavari, M.; Toselli, M. Interpreting Environmental Impacts Resulting from Fruit Cultivation in a Business Innovation Perspective. Sustainability 2020, 12, 9793. [CrossRef]

9. Djaman, K.; Koudahe, K.; Darapuneni, M.; Irmak, S. Chilling and Heat Accumulation of Fruit and Nut Trees and Flower Bud Vulnerability to Early Spring Low Temperatures in New Mexico: Meteorological Approach. Sustainability 2021, 13, 2524. [CrossRef]

10. Živković, I.P.; Jurić, S.; Vinceković, M.; Galešić, M.A.; Marijan, M.; Vlahovićek-Kahlina, K.; Mikac, K.M.; Lemic, D. PolyphenolBased Microencapsulated Extracts as Novel Green Insecticides for Sustainable Management of Polyphagous Brown Marmorated Stink Bug (Halyomorpha halys Stål, 1855). Sustainability 2020, 12, 10079. [CrossRef]

11. Li, H.; Bolarić, S.; Vokurka, A.; He, J.; Wang, D.; Li, X.; Mešić, A.; Wang, J.; Duralija, B. Genetic Variability and Structure of Fragaria nilgerrensis Schlecht. Germplasm in Sichuan Province. Horticulturae 2021, 7, 353. [CrossRef]

12. Khan, M.R.; Khan, M.A.; Habib, U.; Maqbool, M.; Rana, R.M.; Awan, S.I.; Duralija, B. Evaluation of the Characteristics of Native Wild Himalayan Fig (Ficus palmata Forsk.) from Pakistan as a Potential Species for Sustainable Fruit Production. Sustainability 2022, 14, 468. [CrossRef]

13. Ilhan, G.; Gundogdu, M.; Karlović, K.; Židovec, V.; Vokurka, A.; Ercişli, S. Main Agro-Morphological and Biochemical Berry Characteristics of Wild-Grown Sea Buckthorn (Hippophae rhamnoides L. ssp. caucasica Rousi) Genotypes in Turkey. Sustainability 2021, 13, 1198. [CrossRef]

14. Jaćimović, V.; Božović, D.; Ercisli, S.; Bosančić, B.; Necas, T. Sustainable Cornelian Cherry Production in Montenegro: Importance of Local Genetic Resources. Sustainability 2020, 12, 8651. [CrossRef]

15. Karatas, N.; Ercisli, S.; Bozhuyuk, M.R. Assessment of Morphological Traits, Nutritional and Nutraceutical Composition in Fruits of 18 Apricot cv. Sekerpare Clones. Sustainability 2021, 13, 11385. [CrossRef]

16. Mrázová, M.; Rampáčková, E.; Šnurkovič, P.; Ondrášek, I.; Nečas, T.; Ercisli, S. Determination of Selected Beneficial Substances in Peach Fruits. Sustainability 2021, 13, 14028. [CrossRef]

17. Ondrašek, G.; Romić, D.; Romić, M.; Duralija, B.; Mustač, I. Strawberry growth and fruit yield in a saline environment. Agric. Conspec. Sci. 2006, 71, 155-158.

18. Klamkowski, K.; Treder, W. Morphological and physiological responses of strawberry plants to water stress. Agric. Conspec. Sci. 2006, 71, 159-165.

19. Miličević, T.; Ivić, D.; Cvjetković, B.; Duralija, B. Possibilities of Strawberry Integrated Disease Management in Different Cultivation Systems. Agric. Conspec. Sci. 2006, 71, 129-134. 